\title{
COOPERATIVE AND POLITENESS PRINCIPLES IN UTTERANCES
}

\author{
${ }^{1}$ Asri Syawalia \\ Universitas Bangka Belitung \\ Email: asri.syawalia@gmail.com \\ ${ }^{2}$ Dini Wulansari \\ Universitas Bangka Belitung \\ Email: diniews@gmail.com \\ ${ }^{3}$ Asrul Munazar \\ Universitas Bangka Belitung \\ Email: asrulmunazar01@gmail.com
}

\begin{abstract}
Abstrak
Bahasa yang kooperatif dan sopan dibutuhkan untuk mencapai tujuan percakapan, termasuk menyampaikan gagasan atau mengungkapkan perasaan. Namun, aturan dalam prinsip kerjasama yang digagas oleh Paul Grice berbeda dengan aturan dalam prinsip kesopanan milik Geoffrey Leech. Oleh karena itu, penelitian ini bertujuan untuk menemukan penggunaan prinsip kerjasama dan kesopanan serta hubungannya di dalam ujaran. Subjek dari penelitian ini adalah sebuah film asal Amerika Serikat berjudul Isn't It Romantic. Di dalam penelitian ini, metode yang digunakan adalah metode deskriptif kualitatif. Hasil dari penelitian ini menujukkan bahwa terdapat 53 data yang mengandung prinsip kerjasama dan kesopanan. Oleh karena itu, terdapat juga sebuah hubungan yang berkaitan antara penerapan prinsip kerjasama dan kesopanan dalam ujaran di film ini. Hasil dari penelitian ini diharapkan mampu menjadi panduan untuk menciptakan percakapan yang ideal di masyarakat.
\end{abstract}

Kata Kunci: Prinsip Kerjasama, Prinsip Kesopanan, Hubungan, Ujaran, Konteks

\begin{abstract}
A cooperative and polite language is required to achieve the goal of conversation, either to deliver an idea or express feelings. In spite of that, the rule of cooperative principle proposed by Paul Grice is different from the rule of politeness principle proposed by Geoffrey Leech. Therefore, this study aims to find out the application of both principles and the relation between the two of them in utterances. To conduct this study, an American movie titled Isn't It Romantic was chosen as the subject. The method used in this research was descriptive qualitative. The findings show that there are 53 data of the application of cooperative and politeness principles. Therefore, there is a correlation between the cooperative and politeness principles in the conversations of this movie. The result of this study is expected to be a guideline to create an ideal conversation in society.
\end{abstract}

Keywords: Cooperative Principle, Politeness Principle, Relation, Utterance, Context 



\section{INTRODUCTION}

Linguistics is a study of language consisting of a lot of rules on how a language is used. One of the branches in linguistics is pragmatics which is the study of language in its context (Birner, 2013:2). There are several subfields in pragmatics including speech act, deixis, reference, presupposition, conversation structure, cooperative principle, politeness principle, and many others. The last two are both principles that one frequently uses in performing utterances and conversations.

Based on Leech, pragmatics should focus more on principle rather than rule such as in grammar (2014:34). Therefore, these principles are crucial in pragmatics. The first kind of principle is the cooperative principle. It rules how a conversation between the speaker and the listener can be effective. Effectivity means that the speaker and hearer can cooperatively understand each other.

The cooperative principle is categorized into four branches or maxims, which are the maxims of quality, quantity, relation, and manner (Grice, 1989:26). To apply the maxim of quality, one has to be genuine and not spurious. Meanwhile, to apply the maxim of quantity, one needs to contribute neither more nor less than required in terms of quantity. For maxim of relation, one should give appropriate contribution related to the context of the conversation. Lastly, to apply the maxim of manner, one has to perform a clear contribution while interacting.

The other kind of principle is the politeness principle which focuses more on favoring others (Leech, 1989:132). The politeness principle consists of six kinds of maxims. They are tact maxim, generosity maxim, approbation maxim, modesty maxim, agreement maxim, and sympathy maxim. To apply the tact maxim, one should minimize the cost and maximize the benefit to the interlocutor. Secondly, to apply generosity maxim, one has to minimize the benefit and maximize the cost to him/herself. Thirdly, to apply approbation maxim, one has to minimize the dispraise and maximize the praise to others. The fourth maxim is the modesty maxim that requires the speaker to minimize the expression of praise and maximize the expression of dispraise to self. In a simple way, one should be modest in front of other people. The fifth maxim is the agreement maxim that requires the speaker to minimize the expression of disagreement and maximize the expression of agreement between self and other. Lastly, to apply the sympathy maxim, one has to minimize the antipathy and maximize the sympathy between self and other. 
These two principles indeed have different kinds of concepts and categories. Meanwhile, it is unknown whether these principles are able to be applied together in conversation at the same time or not. Therefore, this study aims to identify the utterances that apply both principles and the relation between two of them.

\section{RESEARCH METHODOLOGY}

\section{Type of the Research}

The method used in this study is descriptive qualitative method which focuses on data collection, analysis, and writing (Creswell, 2014:187). Creswell (2014:205) also stated that qualitative research takes place in natural settings, where human behavior and events occur. Those are the things being observed in this research. Therefore, qualitative method is a method that is used to analyze human behavior using observation and interpretation of the researcher. Additionally, According to McCombes (2020), descriptive study is used to describe a population, situation, or phenomenon in an accurate and systematic way. In this method, the researcher does not control or manipulate the variables, but only observes and measures them

Leedy and Ormrod (2016:253) propose five different methods in conducting qualitative research; They are case studies, grounded theory, ethnography, content analysis, and phenomenology. This research will use the fourth kind which is content analysis. According to Leedy and Ormrod (2016:257), content analysis is a detail observation that is conducted systematically on a content to identify patterns, themes, or biases. This analysis is conducted on the forms of human communication, including books, newspapers, journals, movies, and many more. One form of human communication analyzed in this research is movie.

\section{Subject of the Research}

The subject of this research is movie. Movie is a literary work that contains a story that represents real-life events. Specifically, an American movie titled Isn't It Romantic was chosen as the subject. This movie was released in 2019. It is a satirical fantasy romantic comedy movie directed by an American movie director. This research focuses on the utterances performed by each of the characters by observing the script and context behind those utterances. 


\section{Data Collection}

In this study, there are several steps conducted to collect the data including watching the movie in order to understand the story and context behind it, rewatching the movie and paying attention to the script in order to find out the utterances that apply cooperative and politeness principles, classifying the utterances that consist of the application of both cooperative and politeness principles, and putting the data that have been classified into a table.

\section{Data Analysis}

Creswell (2014:195) stated that data analysis in qualitative research aims to understand the text and image data. There are several steps conducted to analyze the data including interpreting the data. In this step, there were found several aspects which are the context of the utterance, the maxim contained in the utterance, how the maxim is observed, why the maxim is observed, and lastly what the relation between the cooperative and politeness principles in that context is. Further, the researcher has checked the validity of the data and the interpretation with a native speaker from the United States of America. The other steps are displaying the data and concluding the implementation between both principles and the relation between two of them.

\section{FINDING AND DISCUSSION}

Based on the study being conducted, there are 53 suitable data to answer the research question in this study. Among those data, 5 data are displayed as follows:

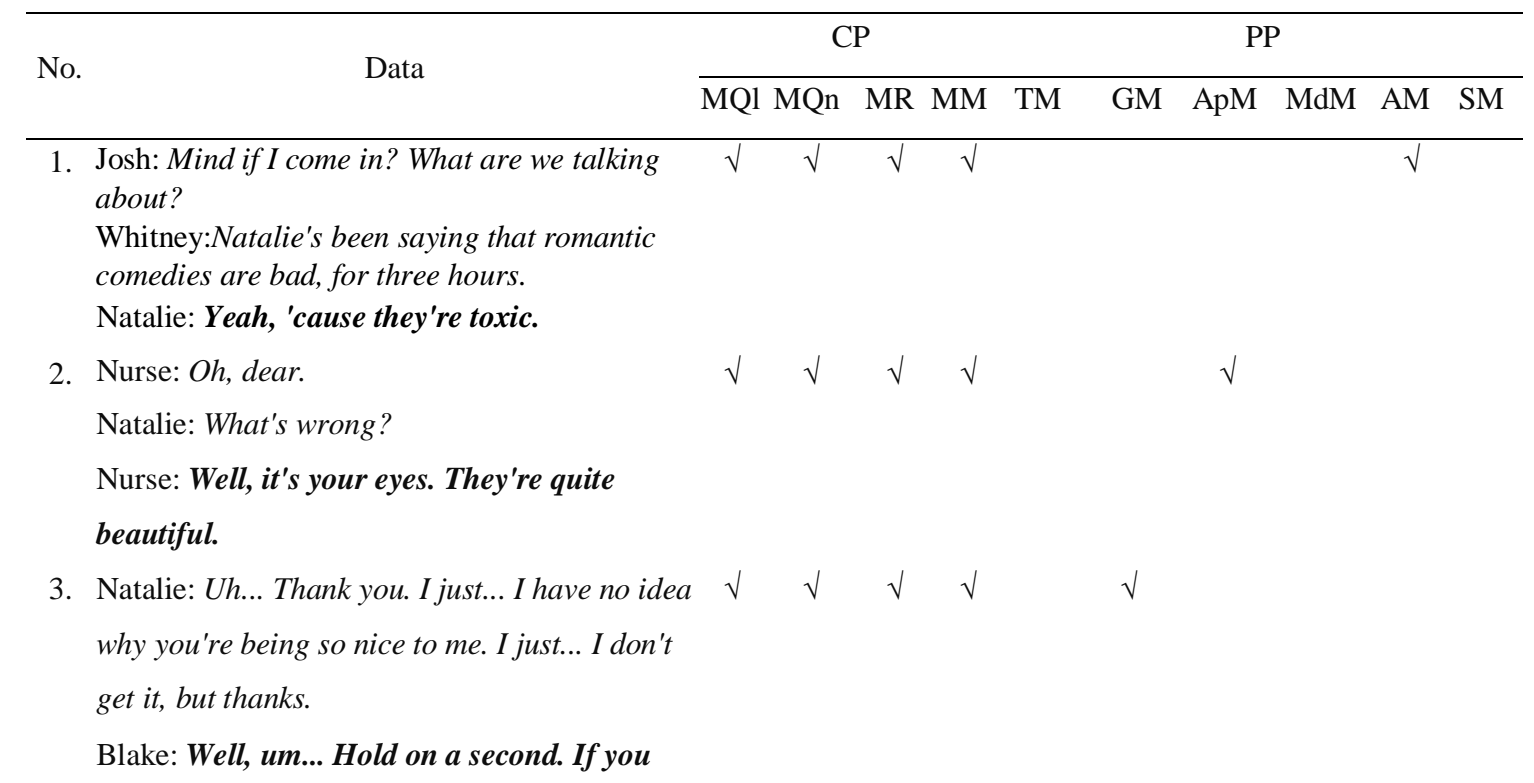


need anything, anything at all, don't hesitate

to give me a call on my cellular telephone

device. There you go. That's my number.

(Writing his number on flower petals

randomly)

4. Natalie: Okay. I hit my head really hard and I

woke up in this alternate universe.

Blake: Okay.

Natalie: And things are supposed to be better,

but it's actually worse because people are

treating me like I'm special.

Blake: Yeah.

Natalie: And I'm not special.

5. Blake: But, um, why don't you do me a favor

and, uh, have dinner with me later, okay?

Natalie: Sure.

Blake: I'll send a car for you.

Table 1. The Relation between Cooperative and Politeness Principles

*)

CP: Cooperative Principle

MM: Maxim of Manner

TM: Tact Maxim

GM: Generosity Maxim

MQI: Maxim of Quality

ApM:Approbation Maxim

MQn: Maxim of Quantity

MdM: Modesty Maxim

\section{Analysis of Data 1}

Natalie caught Whitney, her assistant who was watching romantic comedy during her office hour. Natalie tried to convince Whitney that romantic comedies were bad. Josh heard them arguing and approached them. Whitney explained to Josh what was currently happening, and Natalie agreed to what Whitney said.

Based on the aspect of cooperation, Natalie applied all the maxims in cooperative principle. She accepted Whitney's statement when she said that Natalie had talked about the badness of romantic comedies for three hours. Further, she added that the reason was because they were toxic. Even though her opinion is subjective, it is still categorized as the maxim of quality since she stated what she believed to be true even if other people think it is wrong. In terms of quantity, her statement is also informative enough to contribute to the conversation. It is neither excessive nor deficient. Furthermore, her utterance is in relevance to the topic of romantic comedies. Specifically, her word choice "toxic" is related to the word "bad" in Whitney's utterance. Something toxic is obviously bad for people, in this 
case the fans of romantic comedies. Lastly, how Natalie stated her utterance clearly represents the application of maxim of manner. Meanwhile, based on the order, Natalie responded by firstly agreeing that Whitney was right until she eventually added her opinion about the toxicity of romantic comedies.

In her utterance, Natalie observed the politeness principle by implementing one of the maxims which is the agreement maxim. She agreed to Whitney that she really had talked bad about romantic comedies for three hours since they were really toxic. She did not deny Whitney's statement and tried to maximize the agreement between two of them. Maximizing agreement is a part of being polite in conversation since it decreases the chance for the speakers to argue with each other due to different opinion.

In her utterance, Natalie observed both cooperative and politeness principles. Specifically, there is a correlation among the maxims of quality, quantity, relation, and manner in cooperative principle and the agreement maxim in politeness principle. In this situation, both Natalie and Whitney had a same opinion. It shows that in order to maximize agreement with each other, Natalie did not have to lie to her own feeling and fakes her opinion. Therefore, the maxims of quality agreement are in line as long as the agreement is honest and not forced. Moreover, maximizing agreement can also happen by not giving excessive, unrelated, and unclear information.

\section{Analysis of Data 2}

This dialogue happened in a hospital between Natalie and a nurse. Before that, a thief took Natalie's bag in subway station, Natalie tried to chase him but accidentally hit a pole nearby. She was fainted because of this accident and woke up in an emergency room in a hospital. The nurse then came to the room and examined her. While he was flashing her eyes, he was speechless and amazed by the eyes. Seeing the nurse fell silent, Natalie asked him what was wrong, and he said that her eyes were quite beautiful.

According to the rule of cooperative principle, the nurse obeyed all of the maxims in it. He gave an opinion that Natalie's eyes were beautiful. Observed from his facial expression, it seems that the nurse was sincere to what he said. This is in line with the rule of the maxim of quality where the character should state what is true or what he or she believes to be true. Two sentences he expressed in this 
dialogue are adequate and informative enough to answer Natalie's question. The first sentence, "Well, it's your eyes" is used to answer the question "What's wrong?", and the second one, "They're quite beautiful." is used to explain the first sentence, so that Natalie would not feel confused. If he only answered by the first sentence, Natalie would likely to ask more question about it. Hence, his utterances are compatible to be classified as the maxim of quantity. In addition, his answer is related to Natalie's question. The relevance between the question and answer shows that this conversation consists of the maxim of relation. Lastly, in terms of manner, the nurse provided a clear and consecutive answer that can make Natalie understand easily. There is no ambiguity in his answer. That is why it can be considered as the application of the maxim of manner.

Observed by the theory of politeness, the nurse's answer consists of the approbation maxim in which he maximized praise to Natalie. The praise is contained in his second sentence where he stated that Natalie's eyes were quite beautiful. Further, his sincere facial expression and how he was speechless while flashing Natalie's eyes show that he was really amazed by them. Maximizing praise can be classified as a polite act as it can make the hearer feels happy and proud of themselves.

Discussing about the relation, the nurse was succeeded to observe both cooperative and politeness principles. The maxims of quality, quantity, relation, and manner in cooperative principle correlates with the approbation maxim in politeness principle. What is being focus in here is the relation between the maxims of quality, quantity, and approbation. It can be portrayed that the nurse praised Natalie without telling a lie and giving too much information. Therefore, the maxims of quality and quantity can be observed as long as the application of the approbation maxim does not contain any lie and excessive information. In addition, the praise stated by the nurse is also related to the topic and is clearly stated with no ambiguity

\section{Analysis of Data 3}

Blake took Natalie home from the hospital. When she came out of the car, she was amazed by the new appearance of New York City in the alternate world. The city was beautiful and full of white and pink colors. Without any intention, they passed by a florist. Natalie then suddenly sneezed three times in a row and said that 
she was allergic. Blake offered some help to get her a hankie or a tissue, and she refused it indirectly. She said that she only needed to lie down and would be fine then. After Natalie refused Blake's offer, Blake still asked her to call him anytime she needed help. He then wrote his phone number on flower petals and gave the petals to Natalie so that she could call him.

Blake observed the cooperative principle by applying the maxims of quality, quantity, relation, and manner. In terms of quality of his utterance, Blake was succeeded to maintain its validity. This is proven in another scene when he came to bailed Natalie out of the jail after she called him for help. This is in line with the application of the maxim of quality. In addition, Blake did not state something too much nor too little. This is the reason why the maxim of quantity is applied in this context. Moreover, in terms of relevance, Blake was able to understand what Natalie meant when she refused his offer, and he was also able to relate it by offering himself to help her whenever she needed it in other times. Lastly, the way he stated his utterance is also in order. Firstly, he responded Natalie's words by saying "well", and then added more information about how she could contact him in another time.

In this context, Blake was polite in his utterance. It is because the utterance contains the generosity maxim. That maxim is found when he said that anytime Natalie needed his help, she could just call him. This utterance indicates that Blake was trying to benefit Natalie. Further, there is also a scene that shows how Blake helped Natalie by bailing her out of the jail.

In this condition, there is a link between the cooperative and politeness principles. The maxims that corelate each other are all the maxims in cooperative principle and the generosity maxim in politeness principle. The relation that can be focused in Blake utterance occurs between the maxim of quality and the generosity maxim. Blake was able to be generous by benefitting Natalie yet still proved the validity of his words. Further, he did not state his offer in excessive, irrelevant, and unclear sentences. As long as the character is able to show his or her polite attitude in an effective form of utterance, then the character is also able to juxtapose both principles. 


\section{Analysis of Data 4}

This conversation was situated in front of the police office after Blake guaranteed Natalie to get out of jail after an officer caught her attempting to suicide and jumping the turnstile in a subway station. Natalie then talked about what happened at that time that she entered an alternate universe. She said people started to treat her special and different from what they used to do before.

Natalie was being cooperative in her statement. She obeyed all the maxims in cooperative principle. The first maxim is the maxim of quality. This is proven by the honesty of her statement. She told Blake about what she believed to be true. She had the same opinion when she was still in real life and after entering the alternate universe that she was not special. Second, observed from the aspect of quantity, her reply is considered simple and informative to add more information about what was currently happening at that time. This is probably because she had talked much in the previous utterances, and she tried to make it simple so that Blake would not lose focus and understand better. Third, in terms of relation, her utterance is obviously related to the previous utterances. Specifically, she repeated the word "special" as she stated before. Fourth, the simplicity of her utterance makes her utterance clear enough to be heard and understood. It is in line with the theory of maxim of manner.

Natalie was polite in her utterance. It is indicated when she applied the modesty maxim. It means the character tries to dispraise him or herself in front of other characters instead of praising him or herself excessively. In this context, Natalie's utterance does not contain any compliment for herself at all because "And I'm not special" is the expression of dispraise. Being modest is considered polite as it means that the speaker shows that the other speaker or the listener has a better quality comparing to him or herself.

In this context, Natalie was cooperative and polite in front of Blake. There is a conformity among the maxims of quality, quantity, relation, and manner in cooperative principle and the modesty maxim in politeness principle. This conformity could happen because Natalie maintained the validity of her utterance. In some cases, one might lie to the others in order to be humble in front of them. This is also called white lie. Meanwhile, Natalie was humble yet honest at the same time. Therefore, the modesty maxim in politeness principle is able to be applied at the same time with the maxim of quality in cooperative principle as long as the 
application is true to the reality or what the character feels. Additionally, being modest in this case is able to do without giving excessive and unclear information.

\section{Analysis of Data 5}

When Natalie talked about what happened at that time that she entered an alternate universe, Blake did not really understand it and his father suddenly called him. He left Natalie to answer the phone call, and after that he went back to her, asking her to have a dinner with him. Natalie agreed with it, and Blake offered her a car to pick her up for the upcoming dinner.

Observed from the aspect of politeness, Blake was polite in his utterance. It is because he applied the tact maxim in the theory of politeness. In tact maxim, the character should maximize benefit and minimize cost to others. It is shown when Blake benefitted Natalie so that she did not have to think about the transportation to the restaurant for the upcoming dinner. It also minimizes Natalie's cost such as to pay for a taxi. This act is considered polite as it means that the character pleases the other character and seemed thoughtful.

Blake was cooperative to Natalie. He applied the maxim of quality by saying the truth that he really would send a car for her. This is proven by the other scene that showed Natalie came out of a car that was same as Blake's when he picked Natalie up from the police office. Next, he observed the maxim of quantity by giving a sufficient amount of information to Natalie. Additionally, in terms of relation, his statement is relevant to the topic being discussed. First, he asked Natalie to have a dinner with him. After Natalie agreed, he added that he would send a car. Blake obeyed the maxim of manner as well by responding with a clear and simple sentence. The structure of the sentence and how he stated it was straightforward.

The cooperative and politeness principles in Blake's utterance are in line. The maxims of quality, quantity, relation, and manner in cooperative principle are applied with the tact maxim in politeness principle. The relation that is focused in this condition is the relation between the maxims of quality and tact. The maxim of quality is likely to be achieved when the character benefits the other character yet still be honest and sincere to help. Blake's utterance shows that he benefits Natalie by kindly intending to send her a car for the upcoming dinner, and another scene in this movie also shows that Blake was true to his words. Moreover, Blake also did 
not give any excessive, not to mention irrelevant and unclear statement as a response.

\section{CONCLUSION AND SUGGESTION}

\section{Conclusion}

Based on the data found in Isn't It Romantic movie, several points can be concluded. Firstly, there were found the application of cooperative principle in the movie. The data consist of the maxims of quality, quantity, relation, and manner. It shows that the characters in the movie are capable of being cooperative in the conversation. They are able to make sure the validity of their statement, the suitable amount of information, relation to the context, and the clarity of delivery. Secondly, there were also the application of politeness principle in Isn't It Romantic. They contain the observance of the tact, generosity, approbation, modesty, and agreement maxims. However, among these data, there is no data that shows the implementation of sympathy maxims. The data show that the characters are able to be polite in the conversation. Specifically, they are able to benefit others, cost themselves, praise others, dispraise themselves, and increase agreement with the other characters in the conversation of this movie. Thirdly, there is a correlation between cooperative and politeness principles in the data. These data show that the both of the principles are able to be applied at the same time. It means that the characters are able to be cooperative and polite in conversation in this movie.

\section{Suggestion}

After conducting this study and find out the result, the researcher would like give suggestions for other researchers and the readers. The other researchers are suggested to conduct a similar study on a relation between cooperative and politeness principles in direct communication in real life as it is naturally uttered by humans. Real communication might give a deeper analysis of the relation between the cooperative and politeness principles. Eventually, it is expected that the other researchers are able to find other relations between the two principles. Additionally, the readers are suggested to make use of this research as a guideline to have an ideal conversation with other people. Specifically, in terms of pragmatic, it might be better if the readers are capable of being cooperative and polite at the same time. 


\section{BIOGRAPHY}

Asri Syawalia was born in Pangkalpinang, Bangka on January 22, 1999. She is a undergraduate student in the Department of English Literature, Faculty of Social and Political Sciences, Universitas Bangka Belitung. For more information, contact me on my phone number (0858-9653-5249) or on my Instagram account @asri.sy.

\section{REFERENCES}

\section{a. Textbook:}

Birner, B. J. 2013. Introduction to pragmatics. West Sussex: Wiley-Blackwell.

Creswell, J. W. 2014. Research design: qualitative, quantitative, and mixed method approaches ( $4^{\text {th }}$ ed.). California: SAGE Publication, Inc.

Grice, P. 1989. Studies in the way of words. Cambridge: Harvard University Press

Leech, G. 1989. Principles of pragmatics. New York: Longman Inc.

2014. The pragmatics of politeness. Oxford: Oxford University Press.

Leedy, P. D., \& Ormrod, J. E. 2016. Practical research: planning and design (11 $\left.{ }^{\text {th }} \mathrm{ed}.\right)$. Colorado: Pearson Education, Inc.

\section{g. Internet}

Cardillo, E. 2019. Isn't it romantic. Retrieved from https://subslikescript.com /movie/Isnt_It_Romantic-2452244

McCombes, S. 2020. Descriptive research. https://www.scribbr.com/methodology /descriptive-research/. Retrieved May 17, 2020. 